\title{
Effect of Nickel Particle Size on Eactive Sintering Production of Niti Shape Memory Alloy
}

Pavel Novák, Ivo Marek, Petr Dvořák, Tomáš Veselý, Vladimír Vojtěch, Andrea Školáková, Adriana Bernatiková Department of Metals and Corrosion Engineering, University of Chemistry and Technology Prague, Technicka 5, 16628 Prague 6 - Dejvice, Czech. E-mail: panovak@vscht.cz, ivo.marek@vscht.cz, petr.dvorak@vscht.cz, tomas.vesely@vscht.cz, vladimir.vojtech@vscht.cz, andrea.skolakova@vscht.cz, adriana.bernatikova@vscht.cz

This work is focused on the description of the influence of the particle size of nickel on the synthesis of NiTi shape memory alloy by reactive sintering with high heating rate $\left(300^{\circ} \mathrm{C} . \mathrm{min}-1\right)$. It was found that coarse nickel powders undergo only a limited thermally-activated reaction. On the other hand, too fine powders support the low-temperature $\left(500-800{ }^{\circ} \mathrm{C}\right)$ diffusional formation of $\mathrm{Ni}-\mathrm{Ti}$ intermetallics which could then suppress the rapid thermallyactivated reaction. The optimum powder fraction of nickel to obtain the material with the lowest porosity and fraction of undesirable $\mathrm{Ti}_{2} \mathrm{Ni}$ phase is $25-45 \mu \mathrm{m}$.

Keywords: powder metallurgy, NiTi, reactive sintering

\section{Acknowledgement}

This research was financially supported by Czech Science Foundation, project No. 14-03044S and from Specific University Research (MSMT No. 20/2015).

\section{References}

[1] KRISTIANOVA, E., NOVAK, P. (2015). Properties, Production and Applications of NiTi Shape Memory Alloy. In: Manufacturing Technology, Vol. 15, No. 6, pp. 995 - 998.

[2] NOVAK, P., SKOLAKOVA, A., VOJTECH, V., KNAISlOVA, A., POKORNY, P., MORAVEC, H., KOPECEK, J., KARLIK, M., KUBATIK, T. F. (2014). Application of Microscopy and X-ray Diffraction in Optimization of the Production of NiTi Alloy by Powder Metallurgy. In: Manufacturing Technology, Vol. 14, No. 3, pp. $387-392$.

[3] NOVAK, P., KRIZ, J., MICHALCOVA, A., SALVETR, P. (2015). Role of Reactive Sintering in Production of Technically Important Intermetallics. In: Manufacturing Technology, Vol. 15, No. 1, pp. 74 - 77.

[4] SUZUKI, Y., UNUMA, H. (1988). US Patent 4,719,077.

[5] WHITNEY, M., CORBIN, S. F., GORBET, R. B. (2008). Investigation of the mechanisms of reactive sintering and combustion synthesis of NiTi using differential scanning calorimetry and microstructural analysis. In: Acta Materialia, Vol. 56, No. 3, pp. 559-570.

[6] NOVAK, P., POKORNY, P., VOJTECH, V., KNAISLOVA, A., SKOLAKOVA, A., CAPEK, J., KARLIK, M., KOPECEK, J. (2015). Formation of Ni-Ti intermetallics during reactive sintering at 500-650 ${ }^{\circ} \mathrm{C}$. In: Materials Chemistry and Physics, Vol. 155, pp. 113-121.

[7] NOVAK, P., MEJZLIKOVA, L., MICHAlCOVA, A., CAPEK, J., BERAN, P., VOJTECH, D. (2013). Effect of SHS conditions on microstructure of NiTi shape memory alloy. In: Intermetallics, Vol. 42, pp. 85-91.

[8] Michalcova, A., SVOBOdOVA, P., NOVAKOVA, R., LEN, A., HECZKO, O., VOJTECH, D., MAREK, I., NOVAK, P. (2014). Structure and magnetic properties of nickel nanoparticles prepared by selective leaching. In: Materials Letters, Vol. 137, pp. 221-224.

[9] NOVAK, P., MiChalCOVA, A., SKOlaKOVA, A., PRUSA, F., KRIZ, J., MAREK, I., KUBATIK, T. F., KARLIK, M., HAUSILD, P., KOPECEK, J. (2015). Effect of heating rate on the formation of intermetallics during SHS process. In: Acta Physica Polonica A, Vol. 128, pp. 561-563. 